\title{
The pivotal role of conference papers in the network of scientific communication
}

\author{
Elizabeth Rowley-Jolivet
}

\section{(2) OpenEdition}

Electronic version

URL: http://journals.openedition.org/asp/2394

DOI: $10.4000 / a s p .2394$

ISBN: 978-2-8218-0380-0

ISSN: 2108-6354

Publisher

Groupe d'étude et de recherche en anglais de spécialité

Printed version

Date of publication: 1 December 1999

Number of pages: 179-196

ISSN: 1246-8185

\section{Electronic reference}

Elizabeth Rowley-Jolivet, « The pivotal role of conference papers in the network of scientific communication », ASp [Online], 23-26 | 1999, Online since 22 June 2011, connection on 30 April 2019 URL : http://journals.openedition.org/asp/2394 ; DOI : 10.4000/asp.2394

This text was automatically generated on 30 April 2019

Tous droits réservés 


\title{
The pivotal role of conference papers in the network of scientific communication
}

\author{
Elizabeth Rowley-Jolivet
}

\section{Introduction}

Communication, declared Becher, is "the life-blood of academia".

A fresh insight, a new discovery, a novel invention, unless made available to others in the public domain, will remain more than a piece of private intellectual property, fated to accompany its owner to the grave. (1989: 77)

2 This assertion is echoed, in remarkably similar terms, by Callon, who stresses the necessity for scientific facts to create 'networks' in order to survive:

Un fait scientifique [...] qui demeurerait privé, qui ne se trouverait pas ou ne se construirait pas son propre espace de circulation, serait une contradiction dans les termes [...]. Pour mettre au jour la mystérieuse alchimie qui fournit à un fait scientifique la force qui lui permettra de résister aux critiques et l'espace de circulation sans lequel il disparaitrait, il suffit de lui redonner les réseaux qui sont solidaires de sa fabrication et de sa diffusion. [...] Pour décrire la fabrication d'un fait scientifique, c'est-à-dire le double mouvement par lequel il est construit et trouve des débouchés, il faut donc analyser les réseaux qu'il noue et sans lesquels il serait vidé de tout contenu et de tout avenir. (1989: 14-15)

Sociological analyses of innovation in science and technology have traditionally concentrated on the laboratory as the hub of the network of communication which enables scientific facts to become established (Callon 1989; Callon 1990; Knorr-Cetina 1981; Latour 1987; Latour \& Woolgar 1986; Lynch 1984; Pickering 1984; Woolgar 1982). In this approach, a major constituent of the network of communication, and one of the most powerful allies that are marshalled to build and maintain the network, is the discourse genre of the research article. ${ }^{1}$ While acknowledging the great interest and richness of this body of work, it would appear that there are some gaps in the picture it paints of 
scientific communication, on two levels. The first neglected area concerns scientific conferences: their role - alongside and complementary to that of laboratories - in creating and maintaining scientific networks has never, to our knowledge, been specifically addressed, despite their undoubted importance in this respect (Rowley-Jolivet 1998: 6-7). The second unexplored area concerns conference papers: the specific position and function of this genre, among the various genres of scientific discourse, in the life of scientific facts has received little attention. Analyses to date have focussed either on the structure of biomedical papers (Dubois 1980) or on the negotiation of claims in the question and answer phase following poster sessions (Shalom 1993) or paper presentations (Webber 1997), The present paper therefore has a twofold objective: to attempt to fit scientific conferences into existing analyses of sociotechnical networks, in order to determine their specific contribution; secondly, to position conference papers in relation to other, more widely-studied genres, in order to bring out their particular role in the construction of scientific facts. Not only is this position, we claim, a pivotal one, but a better understanding of the role of conferences and their associated discourse genre leads, we shall argue, to a more balanced view of the vexed question of epistemological relativism and anti-realism².

The paper is organised as follows. We first examine the role of scientific conferences in the sociotechnical networks of science; the second section looks at the network of discourse genres and positions conference papers in this framework, leading to a definition of their role in claim-making. These two sections demonstrate the close connection between conferences and laboratory activity, and this connection not only throws considerable light on many discourse features of conference papers but also provides fresh insight into the nature of scientific activity itself, the subject of the third and final section.

\section{Scientific conferences and sociotechnical networks}

5 The sociology of technoscience bases its analysis on the concept of "actor-networks". These are hybrid networks of human and inanimate 'actors' which, together, weave a strong, finely-meshed web of links to ensure the consolidation and dissemination of the scientific knowledge claims produced in the laboratory. The simplest model of this type of organisation is the economic one of 'inputs' and 'outputs', with the laboratory occupying the focal position of 'centre of production' (Fig. 1). ${ }^{3}$ 
Fig. 1. The laboratory as centre of production

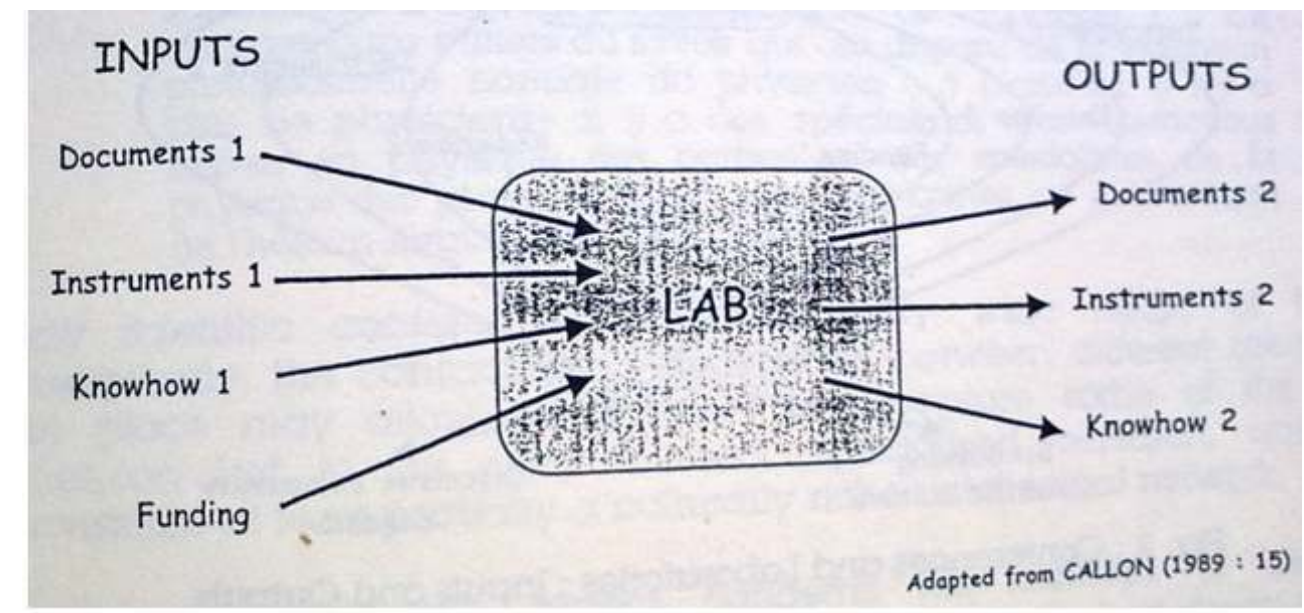

It can be seen that the activity in the laboratory draws on different types of inputs cognitive, instrumental, documentary, and financial - but that the laboratory also needs to create outputs in order for its activity to continue and to create a demand for its products. As a result, the researchers in the laboratory produce articles and submit proposals, develop and perfect new instrumentation, or export their expertise, thus creating a synergy of the various skills acquired.

7 If one now turns from the laboratory to scientific conferences, in order to see where scientific conferences would fit into this kind of model; one finds that conferences constitute both input to the laboratory and provide a forum for its output (Fig. 2).

There is a symbiotic relationship between laboratories and conferences. Among the outputs of the laboratory, much of its research, or cognitive output, will first be presented as conference papers ${ }^{4}$ or posters; new instruments developed by the lab will be 'marketed' via posters or exhibits at a conference; conferences are also a major way for the lab to be represented outside, to show which research areas it has specialised expertise in and thus to achieve public visibility for its activity. Chairing a session, giving a keynote speech, or sitting on the scientific committee of a major conference are all sought-after functions as they give recognition to the status of the lab, or a particular member of it, in a given field. 
Fig. 2. Conferences and laboratories: Inputs and outputs

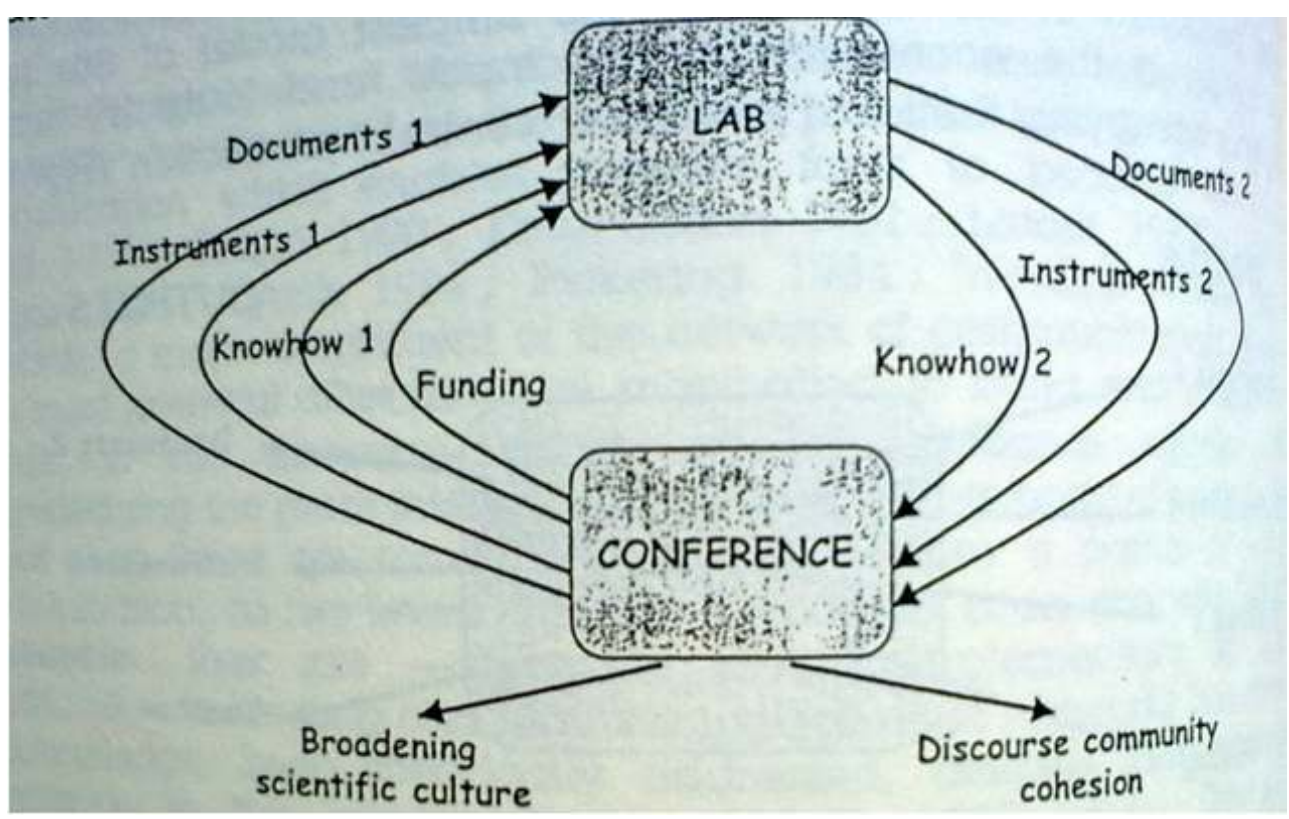

9 In turn, conferences are a major source of input for laboratories. Proceedings papers and oral communications form an important part of the Document 1 input to the laboratory, particularly in fields where technological progress is rapid; new instruments are often brought to the attention of researchers, or even ordered, via the conference exhibitions; an important function of conferences, in science at least, is their role in funding: conferences are one efficient way of forming contacts which will lead to funding and provide credit, as in many of the more applied fields, funding agencies (governments, institutions, etc.) participate in the organisation of the conference, give a plenary lecture and are active participants. Most importantly, the input of scientific know-how of the laboratory is frequently increased thanks to the scientific collaboration that is triggered by meetings at conferences; in addition, the personal contacts made by researchers at a conference allow them to construct their own individual networks, which are often international and transversal in relation to the institutional context in which they carry out their usual activities.

Conferences also play an important role in scientific networks in two other respects which do not fit into this economic model of inputs and outputs, namely, broadening the scientific culture of the participants, and reinforcing social cohesion within the discourse community. As the theoretical physicist Levy-Leblond points out, modern science has become hyperspecialised: the amount of prior knowledge required means that researchers are confined to an increasingly restricted area of scientific activity, leading to an impoverishment in their general scientific culture, which he deplores. In an article entitled "Cherche et re-cherche, ou le crépuscule de la modernité", he comments:

Notre science est moderne, certes elle a rompu avec la tradition. Et elle commence à le regretter. Le vertige de ses succès dans l'infiniment petit, l'infiniment lointain, l'infiniment chaud, l'infiniment passé, l'ont précipitée en une frénétique fuite en avant. Notre savoir aujourd'hui est immense, mais fragile. L'apologie de sa modernité cache mal l'angoisse de sa superficialité. Le savant d'hier était homme de culture, le scientifique d'aujourd'hui est homme de technique. [...] Ce sont des pans entiers du savoir qui ont disparu de la formation professionnelle normale du physicien [...]. D'ailleurs. il n'y a plus de physiciens - il y a des spécialistes des 
interactions faibles en physique des particules, des spécialistes de la physique des

plasmas dilués, des spécialistes de la physique de l'hélium liquide, etc. (1984: 58-59)

(1990: 24-27), after having initially laid down a set of six somewhat constraining criteria
to define a discourse community, subsequently relaxed the constraints, preferring now to
consider a discourse community as a "virtual reality" concept - a construct created by the writer in order to target his claims, similar to the concept of "invoked audience". We would suggest, however, that this virtual reality discourse community loses its virtuality at conferences, and becomes real. Much scientific research is an international, collaborative, effort, and though collaboration can and does go on through e-mail, in all likelihood a large part of it would not have been initiated if the scientists had not first met in person at a conference, and would not continue to thrive if they did not have the opportunity provided by conferences to meet up again at regular intervals. Conferences, in other words, are a strong cement in the social cohesion of a discourse community, making it much more than a disembodied virtual reality concept. The social microcosm constituted by a conference contributes in a very real sense to the feeling of community membership.

In summary for this first part, it can be seen that conferences are in a close, symbiotic relationship with sociotechnical networks; they represent both inputs and outputs of the laboratory, forming a showcase for much of its activity, and at the same time enabling it to recruit more allies - funds, expertise, documents etc. - in order to continue and further its activity, as well as being a crucial factor in the more diffuse network of the discourse community. We now turn to the main discourse genre associated with conferences, namely the conference paper, ${ }^{5}$ in order to examine its role in the establishment of scientific facts.

\section{Conference papers and the life of a scientific fact}

One of the earliest attempts to see how scientific knowledge is established then disseminated through discourse genres is Fleck (1935), Genesis and Development of a Scientific Fact. The basic premise of this work, as the title makes clear, is that scientific 'facts' are not timeless, objective logical entities, but that they have a life - they are born, mature, and eventually die. Reacting against the logico-positivism of his contemporaries in the Vienna Circle, Fleck shows how scientific concepts are contextually situated or even determined, illustrating his case with the example of the development of the medical concept of syphilis: from ethical and religious condemnation, through a primitive jumble of prescientific notions, gradually the specific aetiology of the disease emerged as the 'thought style' of each period and culture changed. An important factor in this development is the role of 'thought collectives', or stable communities of people maintaining intellectual interaction and regular exchange. One of the most stable types of thought collective is science, which Fleck saw as being organised in concentric circles: an esoteric circle of experts in the field, comprising a hard core of specialised experts, then the exoteric circle of the general public, an idea that has become widely accepted within 
the sociology of science and discourse analysis. ${ }^{6}$ Each circle has its own type of discourse or literature: academic journals for the hard core, vademecum or reference works of science for the broader esoteric circle, didactic discourse or textbooks for novices being initiated into the esoteric circle, and popular science for the exoteric circle (Fig. 3). Scientific knowledge spreads out from the central hard core towards the periphery in a centrifugal motion; the exoteric circle may subsequently impact back on the centre in a second, weaker centripetal movement.

Fig. 3. Fleck's model of the spread of scientific knowledge

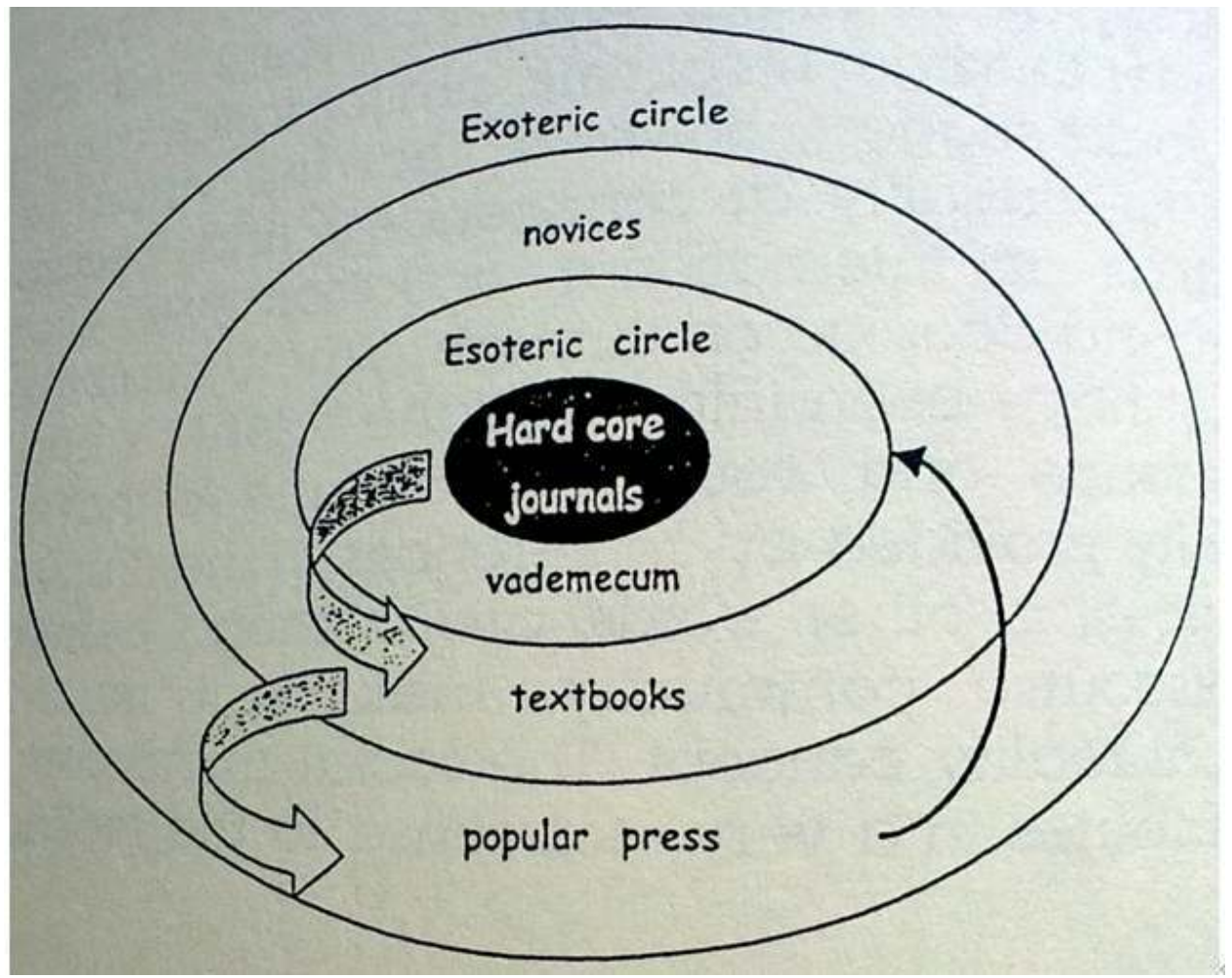

This model has been taken up and re-asserted by Myers (1992), where he quotes a study by Winstanley (1976) which found that in the field of molecular genetics, there was indeed:

[a] very neat pattern of spread, with the structure [of DNA] appearing first in the professional literature, later in university textbooks, later in schoolbooks, and still later in popularizations.

As Myers comments, the more newsworthy discoveries now increasingly tend to make it to the popular press before featuring in textbooks, a trend which no doubt reflects the increasing emphasis placed - by the scientific community itself - on promoting the news value of its activity. ${ }^{7}$

The biological metaphor of 'the life of a fact' is a cornerstone of Latour and Woolgar's (1986) and Latour's (1987) approach to facticity. ${ }^{8}$ In Latour's words (1987: 38):

To survive or to be turned into a fact, a statement needs the next generation of papers [...]. Metaphorically speaking, statements [...]. are much like genes that cannot survive if they do not manage to pass themselves on to later bodies.

Their cline of facticity comprises five types of statement, from the most hypothetical (Type 1) to the least hypothetical (Type 5), and is correlated with the different discourse 
genres. We summarise this in Fig. $4,{ }^{9}$ adapted from Latour \& Woolgar (1986) and Myers (1992).

Fig. 4. Facticity and discourse genres

\begin{tabular}{|l|l|l|}
\hline $\begin{array}{l}\text { Cline } \\
\text { facticity }\end{array}$ & Type of claim & $\begin{array}{l}\text { Discourse } \\
\text { genre }\end{array}$ \\
\hline 5 & Taken-for-granted statements (tacit knowledge) & Lab discussions \\
\hline 4 & Unhedged: "A has a certain relationship with B" & Textbooks \\
\hline 3 & $\begin{array}{l}\text { Positive modality: "It is reported that A has a certain } \\
\text { relationship with B" }\end{array}$ & Journal article \\
\hline 2 & $\begin{array}{l}\text { Hedging: “We do not yet know whether A has a certain } \\
\text { relationship with B" }\end{array}$ & Journal article \\
\hline 1 & $\begin{array}{l}\text { Speculation "X claims that A has a certain relationship with B" } \\
\text { talk }\end{array}$ \\
\hline
\end{tabular}

Myers shows how textbooks and research articles differ in various linguistic and nonlinguistic features such as personal and impersonal subjects, tense, hedging, cohesion, references to other texts, and visualisation. Textbooks present claims as accredited facts that need no hedging, whereas journal articles use heavy hedging; laboratory discussions are characterised by speculation for new or exploratory knowledge at one extreme, and shared, taken-for-granted - and therefore unstated - knowledge at the other.

It appears, from this brief summary of Fleck's and his successors' analyses, that a fact has a life, long or short, in the literature of the field, and that there is a strong correlation between the type of claim and the discourse genre. All the previously quoted sources seem to indicate the configuration for the life of a fact presented in Fig. 5.

Fig. 5. The Life of a Fact - Configuration 1

\begin{tabular}{|l|l|}
\hline & LIFE OF A FACT \\
\hline & genesis \\
\hline 1 & laboratory discussions \\
\hline 2 & negotiation of claims: authors/reviewers \\
\hline 3 & journal publication \\
\hline 4 & citation in other articles \\
\hline 5 & citation in review article \\
\hline 6 & books for specialists \\
\hline
\end{tabular}




\begin{tabular}{|l|l|}
\hline 7 & lectures and student textbooks \\
\hline 8 & schoolbooks \\
\hline 9 & popular press \\
\hline
\end{tabular}

21 This linear model of spread is obviously a simplification and does not represent a continuous time line: some work can go into hibernation, so to speak, and only be discovered, or rediscovered, ${ }^{10}$ long after its original publication. Indeed, Fleck's own work is a case in point: originally published in 1935, it was only brought to public notice, thanks to Thomas Kuhn, forty years later. With this reservation, and taking into account the remark made above concerning the popular press, if a work or finding is never taken up in the literature, then it can be said to die.

However, as can be seen, none of these approaches takes the role of scientific conferences into consideration. We claim, on the contrary, that given the importance of conferences and their associated discourse genre, conference papers, in the network of science, as outlined in the first part of this paper, they both clearly have a place in the construction and dissemination of scientific knowledge. In order to repair this omission, we therefore propose a modified configuration for the life of a fact, in Fig. 6.

23 Conference paper claims can have a short or a long life: if no proceedings are produced for the conference, or if the paper is not selected for publication in the proceedings ${ }^{11}$, it may have a passing impact on the audience present, but will remain basically 'vapourware'; if published in the proceedings, it can then hope to be cited and live longer, as in the previous configuration (Fig. 5).

Fig. 6. The Life of a Fact: Configuration 2

\begin{tabular}{|l|l|l|}
\hline & LONG LIFE & SHORT LIFE \\
\hline 1 & genesis & genesis \\
\hline 2 & conference paper & laboratory discussions \\
\hline 3 & proceedings paper & conference paper \\
\hline 4 & negotiation author/reviewers & \\
\hline 5 & journal publication & (proceedings paper) \\
\hline 6 & citation in other articles & \\
\hline 7 & citation in review article & \\
\hline 8 & books for specialists & \\
\hline 9 & lectures \& student textbooks & \\
\hline
\end{tabular}




\begin{tabular}{|l|l|l|}
\hline 10 & schoolbooks & \\
\hline 11 & popular press & \\
\hline
\end{tabular}

It can be noted, in Configuration 2, that conference papers are situated midway between the highly speculative, oral discussions in the laboratory, and the different written forms of research, where claims can be cited and are more assertively made, even if conventionally hedged. Upstream, the claim in the lab is in an embryonic stage of its development; downstream, the longer it lives in the literature, the more maturity it acquires, becoming finally an undisputed 'fact'. To qualify the type of claim put forward in conference papers, we therefore propose to assign their knowledge claims the status of 'proto-claim'. This is a pivotal, but also a vulnerable, position: the claim advanced in a conference paper can be nipped in the bud during question time, or, less radically, it may be modified and adjusted to take into account various criticisms and remarks made by conference participants; conversely, it may proceed without further impediment to refereed publication and fact-like status. It should be pointed out that this is a generic approach and is not intended as a valid description of all conference papers: some relate research which is in fact in press or ready for publication when the oral communication is given, others - particularly those given to less specialised audiences - relate past research; nor does it apply to plenaries, which bear many similarities to review articles. Nevertheless, situating scientific conference papers as directly downstream from laboratory activity, and seeing them as proto-claims does throw considerable light on various typical discourse features, and it is to these that we now turn.

\section{Conference papers and laboratory work}

Laboratory studies of science by ethnomethodologists and sociologists have resulted in a picture of scientific activity that is radically different from that portrayed in the research article, and this divergence has led in some cases to disillusionment and scepticism: the research article, from this viewpoint, is seen as a 'phoney story', the expression of "an empiricist myth", a purely rhetorical, post hoc reconstruction with little resemblance to reality and therefore no truth value. The inability to reconcile these two versions of science led Gilbert and Mulkay (1984) to posit the existence of dichotomous repertoires in scientists' discourse (the 'empiricist' and 'contingent' repertoires). Likewise Knorr-Cetina (1981), comparing what actually happened in the laboratory with the published version given in the Methods section of the article, concluded in a total lack of correspondence between the two: events underwent a process of transformation, recontextualisation and conversion in the transition from laboratory work to the scientific paper. These apparently irreconcilable divergences have fuelled the debate about epistemological relativism, leading, in extreme cases, to anti-realism: not only is the ability of science to provide true statements about natural phenomena denied, but the very existence of a reality 'out there' is negated. A way out of this impasse is provided by certain philosophical approaches to science which attempt to achieve a balance between theory and experimentation within a diachronic perspective: Chalmers (1982: 161-170) proposes, as a viable alternative to the anti-realist and the realist, or correspondence, theories of 
truth, "unrepresentative realism", while Hacking stresses the importance of experimental practice:

The lesson is: think about practice, not theory. Anti-realism about atoms was very sensible [...] a century ago. Anti-realism about any sub-microscopic entities was a sound doctrine in those days. Things are different now. [...] The best kinds of evidence for the reality of a postulated or inferred entity is that we can begin to measure it or otherwise understand its causal powers. [...] Hence, engineering, not theorizing, is the best proof of scientific realism about entities. (1983: 274).

A study of conference papers can make an important contribution to this debate precisely because of their pivotal position: they 'bridge the gap' between practice on one hand laboratory activity, fieldwork... - and the increasingly theoretical, ${ }^{12}$ rhetorically conventionalised, account of this activity given in the research article on the other, and may thus enable one to put the controversy between realism and relativism in a more accurate perspective. They open a window, so to speak, onto the nature of scientific activity before its formulation in the discourse conventions of the research article, enabling one to draw a more precise topography of the 'work' accomplished by the latter. As Dubois points out in her analysis of biomedical conference presentations, this discourse genre presents a picture of scientific activity which is closer to reality than that found in the research article:

One glimpses research as it is actually conducted, before it is sanitized to present a picture of straightline progress toward public knowledge. (1980: 143)

In order to situate conference papers in relation to actual research activity, it will be useful to first establish an overall view of the main characteristics of laboratory work. Fig. 7 attempts to summarise what are considered, by various observers and analysts in the sociology and philosophy of science, to be its key features. In this section, we will give firstly a brief analysis of each feature and then confront it with the picture of scientific activity which one finds in conference papers, illustrating it by extracts from our corpus. 13

Fig. 7. Characteristic features of laboratory activity

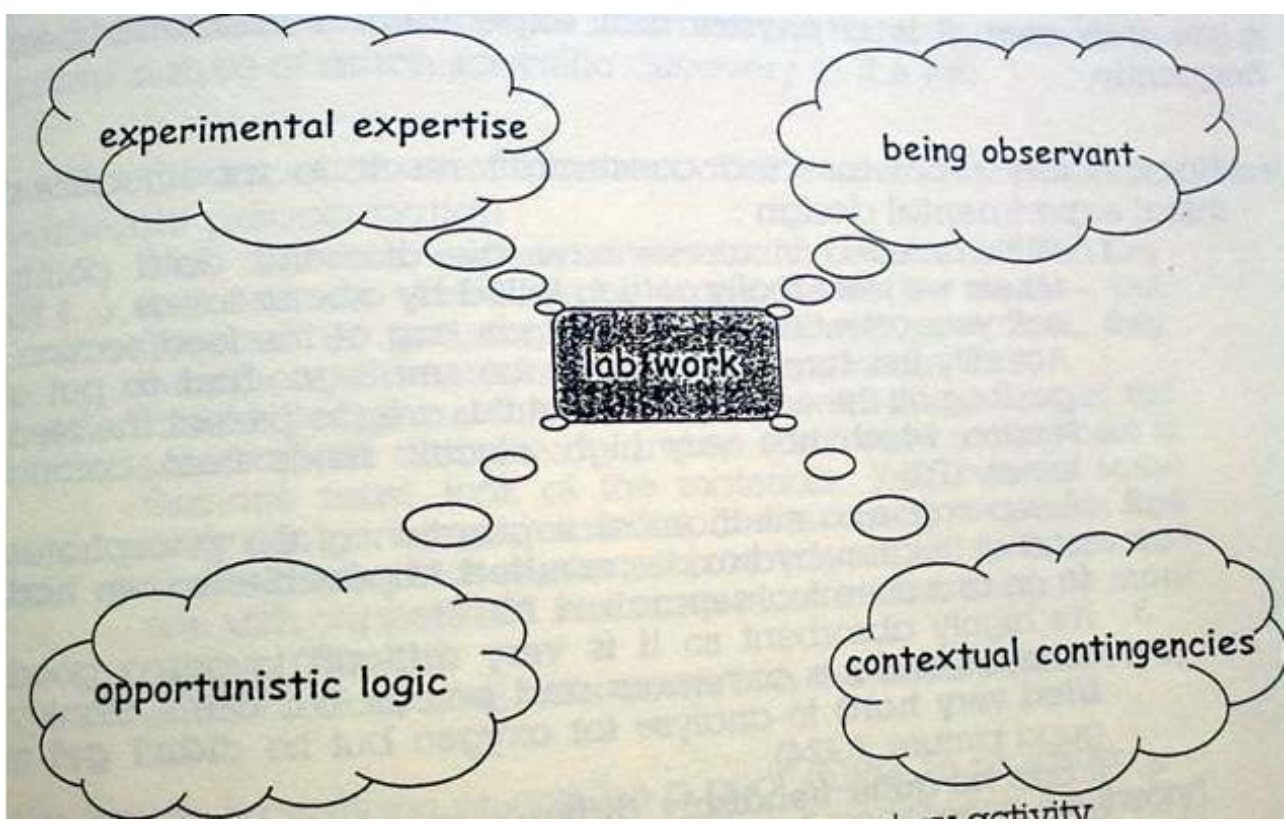




\section{Experimental expertise}

28 As Hacking points out, the epistemological role of experimentation has traditionally been downplayed or even ignored: "Philosophers of science constantly discuss theories and representation of reality, but say almost nothing about experiment" (1983: 149). He suggests that we attend more seriously to the role of experiment in science, for two reasons. Firstly, some experiments prepare the ground for theoretical breakthroughs "Some great theories spring from pre-theoretical experiment" (ibid. 159) - and practical inventions can gradually lead to theoretical analysis: "the inventions [in thermodynamics] proceed at their own practical pace and theory spins off on the side" (p. 163). Secondly, "Experimentation has a life of its own" (p. 150): an experiment is rarely the straightforward application of a theory, as the natural phenomena being investigated impose very real constraints on the research activity itself. The scientific researcher has to contend with an often recalcitrant phenomenal world, and 'manips', as they are familiarly called in French laboratories, frequently prove rather more difficult to manipulate than expected.

Our corpus of conference papers confirms both the importance and the difficulties or challenges posed by real-world experiments. The problems encountered are frankly admitted and are of various kinds: the materials used crack, break or induce unwanted and unforeseen secondary effects; the experimental set-up also holds surprises, and adjustments have to be constantly made to the initial design in order to solve technical problems - called "tinkering" by Knorr-Cetina - while theory frequently offers only a general guideline, or may even be misleading, as to what to expect. The following quotations ${ }^{14}$ demonstrate that experimentation undoubtedly has a life of its own. It is in physics that experimental problems occur most frequently.

Unexpected problems and constraints result in modifications of the initial experimental design:

1. With antenna in air we have the diamond data points where we were really getting killed by corona losses (...) I'll call your attention to this little gas bag at the feed section. Actually this turned out to be too small, we had to put a gas bag all the way up to about this area to protect the feed section which has very high electric fields from corona losses. (P2)

2. A separation, a mechanical separation of the phosphates and of the iron hydroxides resulted impossible, so we had to go to a chemical separation. (G18)

3. It's highly absorbent so it is very difficult to get a good analysis and it is cavernous and porous. (...) Chris Stanley tried very hard to analyse for oxygen but he didn't get a good picture. (G24)

4. It can be quite fiendishly difficult to get one's foot on the horizon (G6)

Tinkering: the experimenter needs to be practically-minded and manually dextrous: ${ }^{15}$

5. I had to build some small and fast Faraday cups to measure the emission off of the surface of these cathodes ... and I fashioned my own Faraday cup this way. It turns out it has a frequency of at least two and a half gigahertz ... along the wall of the diode there is less electron flow so I had to build a bigger Faraday cup, and I again built a machine, a little pin connected to fit inside (P13)

6. In P26, the whole paper is an exercise in problem solving and recounts a succession of modifications to the original experimental set-up in order to eliminate the (unwanted) influence of plasma on the set-up: some modifications are of a highly practical nature (increasing the distance between the various components of the set-up), other require a recourse to theory in order to be solved. 
It is clear from the passages printed in bold type in the above examples that the researchers have to submit, willy-nilly, to considerable constraints and are often forced to abandon their initial line of research during experiments, as indicated by structures such as: "we had to...", the passive ("we were getting killed by..."), adjectives of impossibility ("proved impossible", "fiendishly difficult"), etc. It is also interesting to note the frequent occurrence of the verb "it turned out that...", indicative of the serendipitous nature of much scientific discovery in the lab.

Materials: the importance of a correct choice of materials is a recurrent experimental preoccupation:

7. Well, of course, experimentalists can't behave like God like that and say "Let there be emissions on the anode", but they can do something which is closely equivalent, they can change the material in their experiment (P11)

8. These little lights here have to do with interaction of the plasma with aluminium and so what we're saying here is that one must look at the materials. You can do some nasty things to your satellite [if the wrong materials are chosen] ...Surface materials are important - we covered one with copper and found no more interactions, no more arcing. (P8)

9. in conclusion, it all boils down to a materials problem (P4)

Theory has its limitations or can be a poor guide to practice:

10. The propagation equations are well understood [= theory]. There's some limits on what we need to do and how the parameters are to be adjusted, but that comes with the real world experimentation. (P8)

11. We find in practice that this doesn't seem to present too much of a problem for some reason, I don't know why but if you terminate the line with a resistive load which is slightly more than the characteristic impedance of the line in the unstressed state then the problem with reflections is a lot less than you would expect from the theory - I don't know why that is. (P4)

\section{Being observant}

35 We will again draw on Hacking for his interesting remarks on the importance of observation, in the sense of "being observant", in science:

The good experimenter is often the observant one who sees the instructive quirks or unexpected outcomes of this or that bit of the equipment. You will not get the apparatus working unless you are observant. Sometimes persistent attention to an oddity that would have been dismissed by a lesser experimenter is precisely what leads to new knowledge. (1983: 167)

He also notes that observation is a skill at which some people are intrinsically better than others, though it can be improved by training and practice, and that observing, in the modern laboratory, does not mean seeing with the naked eye but with instruments. Observation has been traditionally considered secondary to, or dependent on, theory - all observation is 'theory-loaded', to use Hanson's (1959) well-known expression - but Hacking makes out a convincing case for the claim that there have been important observations in the history of science which included no theoretical assumptions except in the general sense of the researcher having sufficient knowledge of the field to be able to notice 'interesting' phenomena.

In our data, it is in geology that the need to be observant appears the most clearly. All the retinal variables of the natural phenomena are closely observed, whether it be shape, size, orientation, colour, or texture. During the conference paper, the attention of the 
audience is unceasingly directed towards observation of what is shown visually on the slides, as the continuous extract from the KWIC listing (see table 1) makes clear: overall, half of the 319 occurrences of can in geology are found with a verb of visual perception (principally see, occasionally synonyms such as note, notice, observe).

Table 1. Extract from the KWIC listing

\begin{tabular}{|c|c|c|c|c|c|}
\hline (14) & pyroxene-bearing cumulates. & You & can & see & that the, this dyke \\
\hline (21) & were chromite-rich localities. & You & can & see & that in almost every \\
\hline (26) & across stratigraphy, and & you & can & see & here, this is \\
\hline (28) & this is the, this quarry here, & you & can & see & that there are \\
\hline (31) & stratified elements and I hope & you & can & see & this, but the PGE \\
\hline (37) & across the stratigraphy, and & you & can & see & that we're picking \\
\hline (52) & of these accessory phases, but & you & can & see & picking up this, this \\
\hline (54) & This is the ... here. & You & can & see & these units very \\
\hline (55) & chromite-sulphide-poor unit. & You & can & see & first of all that \\
\hline (57) & compare these two anomalies here & you & can & see & that there's a \\
\hline$(60)$ & interesting thing is that & you & can & see & from these, the \\
\hline (65) & of PGE and indeed nickel & you & can & see & that they, they're \\
\hline (70) & core, in this diagram & you & can & see & the analyses on the \\
\hline (71) & look at the rest of the core & you & can & see & that there are \\
\hline (74) & for these samples and & you & can & see & that they're all \\
\hline (86) & sulphide-bearing horizons. & You & can & see & that there's no \\
\hline (112) & in the secondary environment & & Can & I & have the first slide? \\
\hline$(131)$ & the sample. And here & you & can & see & it's actually very \\
\hline (133) & no outcrop, no exposure and & you & can & see & the traverse comes \\
\hline (135) & up through the sequence and & you & can & see & that the next slide \\
\hline (136) & along this traverse. So & you & can & see & that the track was \\
\hline (137) & higher level, and & you & can & see & that the, there is a \\
\hline (145) & man-made track. But clearly & you & can & see & platinum and palladium \\
\hline
\end{tabular}


During the research process itself, the scientist's visual
observation leads to unexpected or surprising findings:

12. OK, well, what we expected to find from the results of the traverses across the quarry were sulphide and PGE band dunites followed by chromitites followed by sulphide-bearing PGE-enriched dunites. And the first surprise was that sulphides occur throughout each of the boreholes. (G1)

13. ... above we have Triassic material. Below we have Carboniferous material and you have a change here, an upward change in the crystallinity indexes which goes upward, so the wrong way, it should have, many people would have expected to have them low . (G28)

The researcher needs to be receptive to the quirks revealed by microscopic techniques:

14. A very strange animal. This is generally palladium oxide but under the probe my attention was drawn to some peak. This was serium, caesium. (G24)

Observation has its traps as it can prove difficult to distinguish an instrumental artefact from a physical phenomenon:

15. and when we were looking at these we also discovered this particular mineral here. I was labouring up the peaks [i.e. examining the peaks on a chromatogram] and there was one here and it turned out to be a carbon peak. Now the samples are carbon-coated but the carbon coating peak is a very small one -you can see it here and here- and so there is a platinum-oxygen-carbon mineral which just might be a platinum carbonate, and that's sort of unusual. (G2)

These few examples, selected among many, show the crucial importance of observation in scientific activity. Observable reality forces itself on the researcher's attention, and decisions have regularly to be made as to whether the unexpected event is significant or not; if it is judged to be so, this then leads to a fresh trail of investigation, unplanned at the outset.

\section{Opportunism and contextual contingencies}

The final two aspects of laboratory research which surface in conference papers, but which are expurgated from the published research article, concern what Knorr-Cetina calls opportunism (1981: 46). Her study of laboratory life led her to conclude that much scientific research is indexical or locally situated, i.e. subject to specific conditions of time, place, available people and equipment:

a close look at the research scene forces us to bring space and time back into scientific operations, and to conceive of them as locally situated operations (1981:

33)

The consequence of this indexicality is that the logic of much research is an opportunistic logic, not the logic of abstract theorising. The following excerpts will illustrate this feature.

The subject of research itself can be contingent:

16. as I was playing with these with the different cathodes, I found it's sometimes very difficult to turn on with just a hundred kilovolts a nice beam, so I launched off into a little study of the variety of cathodes that are available for such low voltage systems. (P13)

17. We were looking at mutations of $\mathrm{p} 53$ and of K-ras looking for prognostic implications and we used this as an opportunity to look at a different question, as sort of a of a piggyback project on the prognostic implication. (M1)

Some procedures are carried out on a rather random basis: 
18. there's been no specific protocol. It's just been by gosh and by golly a little bit (M6)

$$
\text { This }
$$
played by conferences in sociotechnical networks: due to the symbiotic relationship they enjoy with laboratories, for which they constitute a major form of input and output, as well as their cohesive role in cementing the discourse community, they contribute to consolidating and furthering scientific networks. The pivotal position of conference papers in the life of scientific facts, midway between the embryonic, speculative formulation of claims in the laboratory and the mature, assertive text of the research article, shows claims in the making and has led us to assign the status of 'proto-claim' to the knowledge claims put forward at this stage. We have shown that evidence for this intermediate position of the conference paper genre is found in the numerous traces of the contextual contingencies, problems, constraints and practical reasoning processes inherent in laboratory activity, which subsist in the conference paper but are eliminated in the published article. We argue that conference papers are a transitional locus: thanks to their affinities with laboratory life on one hand, and with public scientific discourse on the other, they bridge the gap between practice (lab activity) and its theorisation (the research article), thus enabling one to avoid falling into the manichean trap of two dichotomous worlds of scientific discourse and to place the debate about epistemological

This study of scientific conferences and their associated discourse genre, the conference paper, has attempted to fill in some gaps in our understanding of how scientific dichotomous worlds of scientific discourse and to place the debate about epistemological 
relativism in a more balanced perspective. We conclude by quoting from a defender of such a balanced stance:

La réaffirmation ressassée de l'objectivité des savoirs scientifiques ne suffit pas, et de loin, à comprendre le statut du savoir scientifique dans notre société. Les défenseurs d'une vision abstraite et neutre de la science font d'ailleurs preuve d'un singulier manque de confiance en la validité des énoncés scientifiques quand ils confondent, comme c'est généralement le cas, une conception constructiviste avec une vision relativiste.

Que l'élaboration de la science soit un processus socialement et culturellement déterminé, les dénominations de ses objets, dans leur indéniable contingence, le montrent à l'évidence; pour ne prendre que deux exemples, les électrons ne trouvent-ils pas leur étymologie dans l'ambre, et les galaxies dans le lait? Mais si les mots gardent la marque de leur histoire, même si on ne l'entend plus, comment n'en irait-il pas de même des idées? [...] Qui, pour autant, nierait non seulement l'efficacité opératoire, mais la valeur cognitive de ces notions? En d'autres termes la relativité historique de la production des idées ne les condamne pas à l'arbitraire, mais exige certes une conception de la validité des connaissances scientifiques plus subtile que celle d'une objectivité abstraite et absolue. (Lévy-Leblond 1998: 37-39)

\section{BIBLIOGRAPHY}

Bazerman, C. 1988. Shaping Written Knowledge. Madison, WI: University of Wisconsin Press.

Becher, Tony. 1989. Academic Tribes and Territories: Intellectual Enquiry and the Culture of Disciplines. Milton Keynes: Open University Press.

Berkenkotter, C. \& T. Huckin. 1995. Genre Knowledge in Disciplinary Communication: Cognition/ Culture/Power. Hillsdale, NJ: Lawrence Erlbaum.

Callon, M. (ed.). 1989. La Science et ses réseaux. Paris: La Découverte.

Callon, M. (ed.). 1990. La science telle qu'elle se fait. Paris: La Découverte.

Chalmers, A.F. 1982. What is this Thing Called Science? 2nd. ed. Indianapolis, IN: Hackett Publishing. Dubois, B.L. 1980. “Genre and structure of biomedical speeches”. Forum Linguisticum V, 140-168.

Fleck, L. 1979 [1935]. Genesis and Development of a Scientific Fact. Chicago, IL: University of Chicago Press.

Gilbert, G.N. \& Michael Mulkay. 1984. Opening Pandora's Box: A Sociological Analysis of Scientists' Discourse. London: Cambridge University Press.

Hacking, Ian. 1983. Representing and Intervening. Cambridge: Cambridge University Press.

Hirschauer, Stefan. 1991. "The Manufacture of bodies in surgery". Social Studies of Science 21, 279-319.

Knorr-Cetina, K. D. 1981. The Manufacture of Knowledge: An Essay on the Constructivist and Contextual Nature of Science. Oxford: Pergamon Press.

Kuhn, T. 1970. The Structure of Scientific Revolutions. 2nd. ed. Chicago, IL: University of Chicago Press. 
Latour, Bruno. 1987. Science in Action. Cambridge, MA: Harvard University Press.

Latour, Bruno \& Steve Woolgar. 1986. Laboratory Life: The Social Construction of Scientific Facts. Princeton NJ: Princeton University Press.

Law, John. 1985. “Les textes et leurs alliés”. Culture technique 14, 59-69.

Lévy-Leblond, Jean-Marc. 1984. L’Esprit de sel, Paris: Fayard.

Lévy-Leblond, Jean-Marc. 1998. “La méprise et le mépris”. Alliage 35-36, 27-42.

Lynch, Michael. 1984. Art and Artefact in Laboratory Science: A Study of Shop Work and Shop Talk in a Research Laboratory. London: Routledge and Kegan Paul.

Myers, G. 1992. "Textbooks and the sociology of scientific knowledge”. ESP 11, 3-15.

Pickering, A. 1984. Constructing quarks. Chicago, IL: Chicago University Press.

Rowley-Jolivet, Elizabeth. 1998. "La Communication scientifique orale : étude des caractéristiques linguistiques et discursives d'un genre”. Thèse de doctorat, Université Bordeaux 2.

Shalom, Celia. 1993. "Established and evolving spoken research process genres: Plenary lecture and poster session discussions at academic conferences". ESP 12, 37-50.

Swales, John. 1986. “Citation analysis and discourse analysis”. Applied Linguistics 7/1, 39-56.

Swales, John. 1990. Genre Analysis. Cambridge, UK: Cambridge University Press.

Webber, Pauline. 1997. "From argumentation to argument: Interaction in the conference hall". ASp 15-18, 439-450.

Woolgar S. 1982. "Laboratory studies: A comment on the state of the art". Social studies of science 12/4, 481-499.

\section{NOTES}

1. See in particular Latour 1987, Chapter 1, "Literature".

2. The most spectacular example of this debate in recent years is of course the 'Sokal affair', as it has come to be called.

3. This economic model is, as Callon makes clear, an oversimplification, since the inputs and outputs do not pre-exist but need to be actively created, mobilised and negotiated; moreover, each input and output in itself represents a whole network of alliances, and the role of the laboratory can be more accurately considered as the "spokesman" for these interconnected networks. However, for our purposes here, this basic model will suffice. For a study of how a laboratory is born by building up a strong network of alliances, see Callon, M. \& Law, J. «La protohistoire d'un laboratoire ", In Callon (ed.) 1989; for a study of how a laboratory dies when it no longer manages to sustain the network, see Callon, M. "L'agonie d'un laboratoire", op. cit.

4. Many conference papers present research that is at a preliminary stage or is still in progress, and therefore constitute the first 'public appearance' of the research in question (Rowley-Jolivet 1998: 488-493).

5. Keynote speeches and plenary lectures have not been included, as it is hypothesised that they form a different genre to the conference paper.

6. See in particular Kuhn 1970; Bazerman 1988; Myers 1992.

7. Berkenkotter, C. \& Huckin, T. (1995 27-44) "News Value in Scientific Journal Articles".

8. Citation analysis also uses the same biological metaphor: Swales (1986) talks of "decay curves" and "citation half-lives". 
9. Latour defines positive and negative modalities as follows: "We will call positive modalities those sentences that lead a statement away from its conditions of production, making it solid enough to render some other consequences necessary. We will call negative modalities those sentences that lead a statement in the other direction towards its conditions of production and that explain in detail why it is solid or weak instead of using it to render some other consequences more necessary. (1987: 23)

10. According to one of our specialist informants in physics, this is a fairly regular occurrence, particularly for less important facts, many of which can lie dormant for decades.

11. A comparison of the number of papers given at an international physics conference in electromagnetism, and the number published in the books of proceedings, shows that only twothirds of the papers were selected for publication. (Rowley-Jolivet 1998: 245).

12. Bazerman's diachronic study of spectroscopic articles published over one century (1893-1980) in Physical Review leads him to conclude that "theory has come to permeate writing in physics" (1988: 157).

13. The corpus comprises 90 short (15-20 mn.) conference papers given at international conferences in 1993-94 in 3 fields (geology, medicine and physics) by native and non-native speakers (geology: 10 NS, 20 NNS; medicine: 15 NS, 15 NNS; physics: 15 NS, 15NNS). The papers were filmed then transcribed. See Rowley-Jolivet (1998: Chapter 4) for details of the selection criteria for i) the 3 fields; ii) the 7 conferences ; iii) the 90 papers.

14. Papers are referred to by a letter ( $G$ = geology; $M=$ medicine; $P=$ physics), followed by a number from 1 to 30 (numbers 1-15 in medicine and physics, and 1-10 in geology, are papers given by native speakers; numbers 16-30 in medicine and physics, and 11-30 in geology, are by non-native speakers).

15. Law (1985: 62-63) provides an interesting analysis of the importance of the experimenter's hands - which, without practice or a natural gift, can prove as unreliable as the experimental apparatus itself - and concludes that they form an essential part of any experimental set-up: "l'expérimentateur fait partie du réseau d'éléments qui constitue son expérience [...] [le corps entraîné] représente une énorme cascade d'alliés potentiels, et d'autre part, il y a, comme avec tous les alliés, la possibilité, la probabilité même, qu'il trahisse celui qui le fait agir." This aspect is of course crucial in surgery, where "hands remain the most important instrument for viewing" (Hirschauer 1991: 300), as many passages in our medical corpus make clear.

\section{ABSTRACTS}

The role of scientific conferences and their associated discourse genre, the conference paper, has received little attention in studies of the construction and communication of scientific knowledge. This paper therefore proposes to fit scientific conferences into existing analyses of sociotechnical networks in order to determine their specific contribution to the latter, and to position conference papers in relation to other, more widely-studied genres, in order to bring out their particular role in the construction of scientific facts. We argue that the pivotal position of conference papers, between laboratory activity on one hand and the research article on the other hand, leads to a more balanced perspective on the question of epistemological relativism.

Les analyses existantes de la construction et de la diffusion du savoir scientifique n'ont accordé que peu d'attention au rôle joué par les congrès scientifiques et par le genre discursif qui leur est 
associé, la communication orale de congrès. Nous tentons donc de préciser la place et l'apport spécifique des congrès aux réseaux sociotechniques, et de positionner la communication de congrès par rapport aux genres discursifs plus largement étudiés afin de faire ressortir sa contribution à la construction des faits scientifiques. Nous soutenons que la position charnière de la communication de congrès, entre le laboratoire d'une part et l'article de recherche d'autre part, permet une conception plus juste du relativisme épistémologique.

INDEX

Mots-clés: acteur-réseau, communication de congrès, communication scientifique, congrès scientifique, proto-assertion, relativisme

Keywords: actor network, conference presentation, proto-claim, relativism, scientific communication, scientific conference

\section{AUTHOR}

\section{ELIZABETH ROWLEY-JOLIVET}

Elizabeth Rowley-Jolivet est maître de conférences à l'École Supérieure de Procédés Électroniques et Optiques (ESPEO), Université d'Orléans. Elle a soutenu en 1998 à l'université de Bordeaux 2 une thèse intitulée « La Communication scientifique orale : Étude des caractéristiques linguistiques et discursives d'un genre ». Elle s'intéresse à la sociologie de la science, au discours oral ainsi qu'aux sémiotiques non linguistiques du discours scientifique. Elizabeth.Jolivet@univorleans.fr 